\title{
AMICUS CURIAE BRIEF SUBMITTED TO THE APPEALS CHAMBER OF THE SPECIAL TRIBUNAL FOR LEBANON ON THE QUESTION OF THE APPLICABLE TERRORISM OFFENCE WITH A PARTICULAR FOCUS ON "SPECIAL" SPECIAL INTENT AND/OR A SPECIAL MOTIVE AS ADDITIONAL SUBJECTIVE REQUIREMENTS**
}

\section{INTRODUCTORY REMARKS***}

The following amicus curiae brief was written pursuant to the Scheduling Order of the President of the Special Tribunal for Lebanon (STL) of 21 January 2011 regarding case STL-11-01/I. On this same date the Pre-Trial Judge of the STL posed several questions to the Appeals Chamber (Chamber) ${ }^{1}$ pursuant to Rule $68(\mathrm{G})$ of the Rules of Procedure and Evidence. ${ }^{2}$ Three of these questions dealt

* Professor of Criminal Law, Criminal Procedure, Comparative Law and International Criminal Law at the Georg-August Universität Göttingen; Judge at the District Court (Landgericht) Göttingen. [kambos@gwdg.de]. I am grateful to stud. iur. T. Anina Timmermann (Göttingen) for her most valuable assistance.

** The Brief (i.e. excluding the authors' introductory remarks) is published as submitted to the Special Tribunal to Lebanon.

*** These introductory remarks were drafted specifically for inclusion in this volume of Criminal Law Forum and did not form part of the original brief.

${ }^{1} \mathrm{STL}$, Le Juge de la Mise en État, Ordonnance relative aux questions préjudicielles adressées aux juges de la Chambre d'Appel conformément à l'article 68, paragraphe g) du Règlement de Procédure et de Preuve, 21 Janvier 2011 (STL-11-01/I).

${ }^{2}$ Rule $68(\mathrm{G})$ is quite unique in international criminal procedure in that it gives the Pre-Trial Judge the possibility to clarify fundamental questions by way of an interlocutory procedure involving the Appeals Chamber ('The Pre-Trial Judge may submit to the Appeals Chamber any preliminary question, on the interpretation of the Agreement, Statute and Rules regarding the applicable law, that he deems necessary in order to examine and rule on the indictment'.) 
with the crime of terrorism ${ }^{3}$ : (1) Should the Tribunal take into account international notions on terrorism even though Article 2 of the Statute only refers to the Lebanese Criminal Code (LCC)?; (2) If so, is there an international definition of terrorism and how should it be applied?; and (3) If not, how is the Lebanese definition of terrorism to be interpreted by the Chamber? Both the prosecution and the defence submitted extensive briefs dealing, inter alia, with these questions. ${ }^{4}$ Additionally, two amicus curiae briefs were submitted, among them this one, which focused on the subjective side of the crime of terrorism. ${ }^{5}$

On February 16, 2011, the Chamber issued its (interlocutory) decision pursuant to Rule 176bis (A). ${ }^{6}$ The Chamber argues, in a nutshell, that terrorism has become a crime under international law and that the respective international definition influences the (applicable) Lebanese law. It refers to the Brief published here essentially to support its proposal of the subjective side of an international crime of terrorism. ${ }^{7}$ The Brief itself does not, however, support the conclusion

${ }^{3}$ The fourth question referring to terrorism ('If the perpetrator intended to kill a certain person but caused injury or death to other persons, how is his criminal responsibility to be defined?') is irrelevant for our purpose since it deals with the general issue of the subjective attribution of unintended consequences.

${ }^{4}$ Defence Office's submission pursuant to rule 176bis (31 Jan. 2011), available at www.stl-tsl.org/x/file/TheRegistry/Library/CaseFiles/Defence/20110131_STL-1101_R176bis_F0004_DO_Submissions_R176bis.pdf (visited on 31 March 2011), paras. 8-125 (hereinafter 'Defence Brief'); Prosecutor's Brief filed pursuant to the president's order of 21 January 2011. Responding to the questions submitted by the Pre-Trial judge (Rule 176bis) (31 Jan. 2011) www.stl-tsl.org/x/file/The Registry/Library/CaseFiles/Prosecution/20110131_STL-11-01_R176bis_F0003_ OTP_Brief_EN.pdf (visited on 31 March 2011), paras. 6-31 ('Prosecution Brief').

${ }^{5}$ The Brief was registered under STL-11-01/I/AC/R176bis (11 February 2011) and published on www.stl-tsl.org/x/file/TheRegistry/Library/CaseFiles/Registry/ 20110211_STL-11-01_R176bis_F0009_Amicus_Curiae_Ambos_Filed_EN.pdf. The other Brief, still submitted in time (the very sharp deadline was set on 11 February 2011, i.e., 4 days after the Appeals Chamber hearing), was by the War Crimes Research Office of American University, The Practice of Cumulative Charging Before International Criminal Bodies, STL-11-01/I/AC/R176bis (11 Feb. 2011) (visited on 31 March 2011), also published in this issue of Criminal Law Forum.

${ }^{6}$ Interlocutory Decision on the Applicable Law: Terrorism, Conspiracy, Homicide, Perpetration, Cumulative Charging, STL-11-01/I/AC/R176bis, Feb. 16, 2011 ('Decision').

${ }^{7}$ Decision (n. 6 above), para. 57 with fn. 79 , para. 83 with fn. 127 , para. 84 , para. 93 with fn. 162 et seq., para. 95 with fn. 176. 
of the Chamber; in fact, it did not deal with the question whether there exists an international crime of terrorism at all. I have dealt with this question afterwards, critically examining the terrorism part of the Appeals Chamber decision. ${ }^{8}$ I have there basically argued that the Chamber's considerations, albeit innovative and creative, are essentially obiter since the applicable terrorism definition can be found, without further ado, in the Lebanese law. There is no need to internationalize or re-interpret this law, it should be applied before the STL as understood in Lebanese practice. As to the Chamber's affirmation that there is a crime of terrorism under international law, I argued that the available sources indicate, at best, that terrorism is a particularly serious transnational, treaty-based crime which comes close to a 'true' international crime but has not yet reached this status. Notwithstanding that the general elements of this crime can be inferred from the relevant sources of international law.

\footnotetext{
${ }^{8}$ K. Ambos, 'Judicial Creativity at the Special Tribunal for Lebanon: Is There a Crime of Terrorism Under International Law?' (2011) 24 (3) Leiden Journal of International Law 655. For an even more critical view on the decision see B. Saul, 'Legislating from a radical The Hague: the UN Special Tribunal for Lebanon invents an international crime of transnational terrorism', (2011) 24 (3) LJIL 677; S. Kirsch/A. Oehmichen, 'Judges gone astray: The fabrication of terrorism as an international crime by the Special Tribunal for Lebanon', (2011) 1 Durham L.Rev. 32.
} 


\section{TEXT OF THE BRIEF}

\section{ART. 314 LEBANESE CRIMINAL CODE (LCC) AS THE APPLICABLE DEFINITION OF THE CRIME OF TERRORISM}

1. Art. 314 LCC is applicable before the Tribunal by way of the renvoi in Art. 2(a) of the Tribunal's Statute. Not only the text of the Statute but also the travaux clearly indicate that the national Lebanese law should be the only body of law relevant before the Tribunal as to the definition of the relevant offences. ${ }^{1}$

2. Art. 314 LCC provides for a rather broad offence definition requiring, on the objective level (actus reus), "acts [...] liable to create a public danger such as explosive devices" etc. and, on the subjective level (mens rea), a general intent with regard to these objective acts and a - here so called - "general" (normal) special intent ("intended to cause a state of terror"). Art. 314 does not contain further definitional elements, in particular it does not contain a - here so called "special" special intent, i.e., a special intent which, going beyond the "general" special intent of causing terror, requires a particular political or ideological purpose, e.g., "the purpose of coercing a state, or international organization to do or refrain from doing something". ${ }^{2}$ Art. 314 does not require a special motive as part of the offence definition either, e.g., that the perpetrator must be motivated by "ideological or political aspirations". 3

3. While the maxim nullum crimen sine lege (substantive legality), as understood in Lebanese law as a civil law jurisdiction, does, in principle, not allow for the "internationalisation" of domestic criminal law offences ${ }^{4}$ and while Art. 314, providing for a concluding offence definition, is, in principle, not in need of interpretative assistance by international law, ${ }^{5}$ the said maxim does not stand in the way of an interpretation in bonam partem, i.e., an

\footnotetext{
${ }^{1}$ Defence Office's submission pursuant to rule 176 bis (31 Jan. 2011), para. 31, 51, 58.

${ }^{2}$ A. Cassese, 'The Multifaceted Criminal Notion of Terrorism in International Law’ (2006) 4 JICJ, 933, 957.

${ }^{3}$ Ibid.

${ }^{4}$ Defence submission, supra note 1 , para. 60 et seq. (71).

${ }^{5}$ Defence submission, supra note 1, paras. 86-89, 112, 125; Prosecutor's Brief filed pursuant to the president's order of 21 January 2011 Responding to the questions submitted by the pre-trial judge (Rule 176 bis) (31 Jan. 2011), para. 15.
} 
interpretation which would restrict the offence definition in favour of the accused. ${ }^{6}$ Indeed, the Lebanese criminal law itself recognizes the retroactivity bonam partem, in the sense of the French "retroactivité in mitius", ${ }^{7}$ explicitly. ${ }^{8}$ Thus, an amendment of a national criminal law provision in bonam partem would, in principle, be admissible, ${ }^{9}$ also if brought about by international law. ${ }^{10}$ The gist of the issue therefore is whether

${ }^{6}$ The bonam partem exception is generally recognized in civil law jurisdictions, see, as representative works, for France F. Debove, F. Falletti, \& T. Janville, Précis de droit pénal et de procédure pénale, 3rd ed. (Paris: Presses Univ. de France, 2010), pp. 74-75; for Germany C. Roxin, Strafrecht. Allgemeiner Teil, vol. I, 4th ed. (München: Beck, 2006), Section 5 marginal number (mn.) 44 (analogy in bonam partem), 50 (custom in bonam partem), 62 et seq. (retroactivity in bonam partem); for Spain S. Mir Puig, Derecho Penal. Parte General (Barcelona: Editorial Reppertor, 2010), p. 116; J.P. Montiel, Analogía favorable al reo: fundamentos y límites de la analogía in bonam partem en el derecho penal (Madrid: La Ley, 2009), 321 et seq. (on the recognition of supra-legal causes of justification on the basis of an analogy bonam partem which is based on customary law or general principles). The exception is also recognized in the relevant codifications, see for example Art. 112-1 French Penal Code ("retroactivité in mitius"), Section 2 (3) German Penal Code and Art. 2 (2) Spanish Penal Code. In Italy, the majority doctrine admits the analogy bonam partem on the basis of Art. 25 (2) of the Constitution and Art. 14 of the preliminary disposition of the Codice Civile which refers to criminal law, see F. Palazzo, Corso di diritto penale. Parte generale, 2nd ed. (Torino: Giappichelli Editore, 2006), at 142 et seq. with further references on the rich scholarly debate.

${ }^{7}$ See supra note 6 .

${ }^{8}$ Article 3 Lebanese Criminal Code: "Any statute that amends the definition of an offence in a manner that benefits the accused shall be applicable to the acts committed prior to its entry into force, unless an irrevocable judgement has been rendered" (emphasis added). On the Lebanese Law see also Defence submission, supra note 1, para. 74: "[...] reliance upon customary law for the purpose of interpreting the requirements (e.g., a lowering of the applicable mens rea) [...]."

${ }^{9}$ See also Defence submission, supra note 1, para. 74 .

${ }^{10}$ The argument is based on the assumption that Lebanese Criminal law is derived from and still quite close to French criminal law (see also Defence submission, supra note 1, para. 73). While French law does not provide for a particular rule or procedure to "import" customary international law into the domestic legal order, the Constitutional Council (Conseil Constitutionnel) examines the compatibility of national law with customary international law and thus recognizes the (de facto) precedence of the latter (cf. Conseil Constitutionnel, Décisions no. 75-59 DC of 30 Dec. 1975; no. 82139 DC of 11 Feb. 1982; no. 85-197 DC of 23 Aug. 1985; no. 92-308 DC of 09 April 1992; summarizing http://www.conseil-constitutionnel.fr/conseil-constitutionnel/ root/bank/pdf/conseil-constitutionnel-17499.pdf, No. 9). Thus, it can safely be argued that also the Lebanese legal order, absent any opposing constitutional or other provision, would accept this precedence and therefore also admit a bonam partem amendment of its criminal law brought about by international (customary) law. 
international law calls for such a bonam partem interpretation with respect to the two additional subjective elements mentioned above.

\section{PRELIMINARY CONSIDERATION: MOTIVES IN CRIMINAL LAW}

4. As a general rule, intent and motive must be distinguished in criminal law. The principle of culpability requires that the perpetrator acts with a certain state of mind, normally with intent; her possible motive(s), i.e., the reason(s) why she performed the act is (are) irrelevant in this respect. ${ }^{11}$ This - here so called -irrelevance thesis has been correctly recognized by the international case law. ${ }^{12}$ Thus, in principle, a certain motive only becomes relevant at the sentencing stage as a mitigating or aggravating factor. ${ }^{13}$

5. The irrelevance thesis requires two qualifiers, though. First, the legislator may include certain motives in the offence definition and make them part of the mens rea element, in particular of a special intent. ${ }^{14}$ Thus, for example, according to the EU Framework Decision on Combating Terrorism the perpetrator

${ }^{11}$ G. Fletcher, Rethinking Criminal Law (Boston: Little Brown, 1978), p. 452; A. Cassese, International Criminal Law, 2nd ed. (Oxford: Oxford University Press, 2008), p. 168.

12 Prosecutor v. Tadic, Appeals Judgement (Case No. IT-94-1-A), 15 July 1999, paras. 270, 272 ("[...]under customary law, 'purely personal motives' do not acquire any relevance [...]"); Prosecutor v. Limaj et al., Appeals Chamber Judgement (No. IT-03-66-A), 27 Sept. 2007, para. 109 ("motive is generally not an element of criminal liability"); Prosecutor v. Jelisić, Appeals Chamber Judgement (No. IT-95-10-A), 5 July 2001, para. 49 ("[...] existence of a personal motive does not preclude the perpetrator from also having the specific intent [...]"), para. 71 ("[...] the irrelevance and inscrutability of motives in criminal law' insofar as liability is concerned, where an intent - including a specific intent - is clear."); Prosecutor v. Kvočka, Appeals Chamber Judgement (No. IT-98-30-1-A), 28 Feb. 2005, para. 106 ("[...] it has repeatedly confirmed the distinction between intent and motive [...]"). See also: G. Mettraux, International Crimes and the Ad-hoc Tribunals (Oxford: Oxford University Press, 2005), p. 211; A. Zahar/G. Sluiter, International Criminal Law (Oxford: Oxford University Press, 2008), p. 180; J.M. Gómez-Benítez, El Exterminio de Grupos Políticos en el Derecho Penal Internacional etc., Revista de Derecho y Proceso Penal No. 4 2000, p. 147, 151; K. Ambos \& S. Wirth, 'The Current Law of Crimes Against Humanity. An Analysis of UNTAET Regulation 15/2000', (2002) 13 Criminal Law Forum, p. 45.

${ }^{13}$ Cf. Tadić Appeals Judgement, supra note 12, para. 269 ("motive becomes relevant at the sentencing stage in mitigation or aggravation of the sentence").

${ }^{14}$ See K. Ambos, Der Allgemeine Teil des Völkerstrafrechts (Berlin: Duncker \& Humblot, 2002), pp. 413-414. 
must act with the aim to intimidate a population, or compel a Government to perform or abstain from performing any act, or destabilise the structures of a country. ${ }^{15}$ Secondly, there is a classical scholarly discussion whether certain motives or convictions of an "délinquant par conviction" (,Gewissenstäter") may exclude her criminal responsibility (by way of a cause of justification or excuse). ${ }^{16}$ Yet, while this would make motives relevant at the level of attribution, it does not affect the constituent elements of the offence (the actus reus, élément matériel, ${ }^{17}$ tipo, Tatbestand), i.e., the "délinquant par conviction" fulfills the elements of the actus reus, she acts, by all means, "tipicamente" (,,tatbestandsmäßig“).

${ }^{15}$ Council Framework Decision on Combating Terrorism, 13 June 2002 (2002/ 475/JHA), Art. 1: “[...] where committed with the aim of: (i) seriously intimidating a population, or (ii) unduly compelling a Government or an international organisation to perform or abstain from performing any act, or (iii) seriously destabilising or destroying the fundamental political, constitutional, economic or social structures of a country or an international organisation."

${ }^{16}$ See most recently C. Roxin, Noch einmal: Zur strafrechtlichen Behandlung der Gewissenstat, GA 158 (2011), p. 1 et seq., who argues that the conviction of a perpetrator can never justify the commission of a criminal offence (at 5) but the act may be excused if only insignificant harm was caused (at 15); H.J. Hirsch, Strafrecht und Überzeugungstäter (Berlin: Walter de Gruyter) (Schriftenreihe der Juristischen Gesellschaft zu Berlin, vol. 147) 1996, arguing that a perpetrator may be justified if she acts because of a serious moral conflict (at 20-21) while a political motivation can only be taken into account as a mitigating factor (at 27-28); generally for a justification: K. Peters, 'Überzeugungstäter und Gewissenstäter', in G. Friedrich \& W. Naucke (eds.), Festschrift für H. Mayer (Berlin: Duncker \& Humblot, 1966), p. 257 et seq., at 276; for an excuse: U. Bopp, Der Gewissenstäter und das Grundrecht der Gewissensfreiheit (Karlsruhe: C.F. Müller, 1974), p. 249 et seq.; against an exclusion of responsibility J. Baucells I Lladós, La delincuenia por convicción (Valencia: Tirant Lo Blanch, 2000), p. 387.

${ }^{17}$ The French doctrine on the structure of the crime (théorie de l'infraction pénale) has traditionally been governed by an elements theory distinguishing between élément légal, matériel, injuste and moral/psychologique/intellectuelle (see K. Ambos, 'Réflexions sur la théorie française de l'infraction pénale du point de vue allemand', in J. Leblois-Happe (ed.), Vers un nouveau procès pénal? (Paris: Société de Législation comparée, 2008), 147 et seq.; in German: Zur Entwicklung der französischen Straftatlehre - Bemerkungen aus deutscher Sicht, ZStW 120 (2008), 180 et seq. (with further references). Accordingly, the élément matériel can be compared to the actus reus (see ibid., 154 or 187) although other authors would rather compare the objective offence definition with the élément légal (see ibid., 152 et seq. or 185 et seq.). Modern authors opt for a new terminology more similar to the German Tatbestand or the Italien and Spanish tipo, see e.g. X. Pin, Droit pénal général, 3rd ed. (Paris: Dalloz, 2009), at 117 et seq. (fait typique). 


\section{DOES INTERNATIONAL LAW PROVIDE FOR A "SPECIAL" SPECIAL INTENT AS AN (ADDITIONAL) ELEMENT OF THE TERRORISM OFFENCE?}

6. Of the relevant primary sources of international law - (i) international conventions, (ii) international custom and (iii) general principles of law (Art. 38 ICJ Statute) - only the first and third one contain explicit and unambiguous information as to the subjective side of the terrorist offence. Yet, on the basis of this information it may be possible to establish an (emerging) norm of customary international law.

\subsection{Treaty Law, Including Drafts}

\subsubsection{Universal Conventions}

7. Thus far it has not been possible to agree on a universal definition of terrorism. ${ }^{18}$ Notwithstanding, 13 international conventions ${ }^{19}$ and several UN Security Council resolutions ${ }^{20}$ dealing with certain

${ }^{18}$ Cf. R. Arnold, The ICC as a New Instrument for Repressing Terrorism (Ardsley, NY: Transnational Publ., 2004), p. 3.

${ }^{19}$ Convention on Offences and Certain Other Acts Committed On Board Aircraft (hereinafter quoted as 'Aircraft Convention'), 1963; Convention for the Suppression of Unlawful Seizure of Aircraft ('Unlawful Seizure Convention'), 1970; Convention for the Suppression of Unlawful Acts against the Safety of Civil Aviation ('Civil Aviation Convention'), 1971; Convention on the Prevention and Punishment of Crimes Against Internationally Protected Persons ('Diplomatic Agents Convention'), 1973; International Convention against the Taking of Hostages; 1980 Convention on the Physical Protection of Nuclear Material ('Hostages Convention'), 1979; Convention on the Physical Protection of Nuclear Material ('Nuclear Materials Convention'), 1980; Protocol for the Suppression of Unlawful Acts of Violence at Airports Serving International Civil Aviation, supplementary to the Convention for the Suppression of Unlawful Acts against the Safety of Civil Aviation ('Airport Protocol'), 1988; Convention for the Suppression of Unlawful Acts against the Safety of Maritime Navigation ('Maritime Convention'), 1988; Protocol for the Suppression of Unlawful Acts Against the Safety of Fixed Platforms Located on the Continental Shelf ('Fixed Platform Protocol'), 1988; Convention on the Marking of Plastic Explosives for the Purpose of Detection ('Plastic Explosives Convention'), 1991; International Convention for the Suppression of Terrorist Bombings ('Terrorist Bombing Convention'), 1997; International Convention for the Suppression of the Financing of Terrorism ('Terrorist Financing Convention'), 1999; International Convention for the Suppression of Acts of Nuclear Terrorism ('Nuclear Terrorism Convention'), 2005. All conventions can be found at: www.un.org/terrorism/instruments.shtml.

${ }^{20}$ S/RES/635 (1989); S/RES/687 (1991); S/RES/748 (1992); S/RES/731 (1992); S/RES/1044 (1996); S/RES/1054 (1996); S/RES/1189 (1998); S/RES/1214 (1998); S/RES/1267 (1999); S/RES/1333 (2000); S/RES/1363 (2001); S/RES/1368 (2001); 
aspects of terrorism exist. Yet, these instruments are not consistent as to the subjective requirements of the offence definition. Some conventions do not contain any subjective element but only provide for the objective elements of the offence, e.g. seizing control of an aircraft. ${ }^{21}$ Other conventions are limited to a general intent requirement, ${ }^{22}$ i.e., they only require that the perpetrator acts with knowledge (cognitive element) and intent (volitive element) with regard to the objective elements of the offence. Thus, for example, the Civil Aviation Convention provides in its Art. 1 that "any person commits an offence if he [...] intentionally [...]" performs any one of the following acts.

8. Several conventions contain a double ("general" and "special") special intent, i.e., they require, on the one hand, a "general" special intent targeted either at "causing death or serious bodily injury or extensive destruction of a place, facility or system" or at "provoking a state of terror" and, on the other hand, a "special" special intent aimed at coercing a government or international organisation to do or abstain from performing any act. ${ }^{23}$ Thus, the question arises whether these different ("general" and "special") special intents must be fulfilled cumulatively ${ }^{24}$ or alternatively. ${ }^{25}$ The wording speaks for the latter view since the intents are always linked by the conjunction "or".

9. There are only two conventions which exclusively provide for a "special" special intent by requiring the purpose to compel a

Footnote 20 continued

S/RES/1373 (2001); S/RES/1377 (2001); S/RES/1438 (2002); S/RES/1440 (2002); S/ RES/1450 (2002); S/RES/1452 (2002); S/RES/1456 (2003); S/RES/1465 (2003); S/RES/1516 (2003); S/RES/1526 (2004); S/RES/1530 (2004); S/RES/1535 (2004); S/ RES/1540 (2004); S/RES/1566 (2004); S/RES/1611 (2005); S/RES/1617 (2005); S/RES/1618 (2005); S/RES/1624 (2005); S/RES/1625 (2005); S/RES/1631 (2005); S/ RES/1673 (2006); S/RES/1699 (2006); S/RES/1730 (2006); S/RES/1732 (2006); S/RES/1735 (2006); S/RES/1787 (2007); S/RES/1805 (2008); S/RES/1810 (2008); S/ RES/1822 (2008); S/RES/1904 (2009); S/RES/1963 (2010).

${ }^{21}$ Aircraft convention, Art. 2 (1); Unlawful seizure convention, Art. 1; Convention on the Marking of Plastic Explosives for the Purpose of Detection, Art. 2.

${ }^{22}$ Civil Aviation convention, Art. 1; Diplomatic Agents Convention, Art. 2; Maritime Convention, Art. 3 (1); Fixed Platform Protocol, Art. 2 (1).

${ }^{23}$ Terrorist Financing Convention, Art. 2 (1)(b); Nuclear Terrorism Convention, Art. 2 (2)(b). A similar wording is also employed in Art. 2 (1) of the Draft Comprehensive Convention on International Terrorism, UN SC Resolution 1566, S/Res/ 1566, 8. Oct. 2004, para. 3.

${ }^{24}$ As suggested in the Pre-Trial Judge's order of 21 Jan. 2011, paras. 7 (c) and (e).

${ }^{25}$ As suggested in the OTP submission, supra note 5, para. 20. 
state or an organisation to perform or abstain from doing any act. $^{26}$ Yet, these two conventions only criminalize very specific acts of terrorism (taking of hostages and abusing nuclear materials). In addition, the Nuclear Materials Convention only requires this "special" special intent for the actus reus alternative of threatening to abuse nuclear materials whereas the actus reus alternative of actually committing the offence, i.e., actually abusing nuclear materials, only requires a general intent.

\subsubsection{Regional Instruments}

10. In Europe there are two documents of relevance to our question. The European Convention on the Suppression of Terrorism only refers to most of the above mentioned international conventions $^{27}$ and does not add any further subjective requirements. $^{28}$ The Framework Decision ${ }^{29}$ on Combating Terrorism proposes a terrorism definition with three special intents, namely a "general" special intent aimed at causing a state of terror, a "special" special intent targeted at coercing the state to do or abstain from performing any act and, last but not least, a "special" special intent directed at destabilizing or destroying the structure of a country. ${ }^{30}$ The different intents are connected

\footnotetext{
${ }^{26}$ Hostages convention, 1979, Art. 1 (1); Convention on the Physical Protection of Nuclear Material, 1980, Art. 7 (1)(e)(ii).

${ }^{27}$ Namely to the Unlawful Seizure Convention, Civil Aviation Convention, Diplomatic Agents Convention, Hostages Convention, Nuclear Materials Convention, Airport Protocol, Maritime Convention, Fixed Platform Protocol, Terrorist Bombing Convention, Terrorist Financing Convention.

${ }^{28}$ Council of Europe, European Convention on the suppression of terrorism, 1977, Art. 1; amended by Protocol amending the European Convention on the Suppression of Terrorism, 2003, Art. 1.

${ }^{29}$ Under the old third pillar (police and judicial cooperation) the EU could "adopt framework decisions for the purpose of approximation of the laws and regulations of the Member States. Framework decisions shall be binding upon the Member States as to the result to be achieved [...]" (Art. 34 (2)(b) TEU former version). Framework decisions remain valid under the Treaty of Lisbon (Art. 10 Protocol no. 36 relating to the Lisbon Treaty, Official Journal of the EU, C 115/201 of 9 May 2008).

${ }^{30}$ Council Framework Decision, supra note 15; with identical wording Council Common Position on the Application of Specific Measures to Combat Terrorism, 27 Dec. 2001 (2001/931/CFSP), para. 3.
} 
by the conjunction "or" and therefore only need to exist in the alternative.

11. In the Americas the comprehensive Inter-American Convention Against Terrorism also refers to most of the above mentioned international conventions ${ }^{31}$ and does not contain any additional subjective requirements. ${ }^{32}$ In the same vein, the Convention Against Specific Terrorist Acts Against Persons does not provide for any form of special intent. ${ }^{33}$

12. With regard to Africa the Organization of African Unity's (OAU) comprehensive Terrorism Convention contains three special intents, two of a more "general" nature ${ }^{34}$ and one of a "special" nature. ${ }^{35}$ With these tree forms of special intent it is similar to the EU framework decision mentioned above. ${ }^{36}$

13. In Asia there are two relevant supranational conventions. The Convention on Counter Terrorism by the Association of South East Asian Nations (ASEAN) is only referring to all the above mentioned international conventions ${ }^{37}$ and does not add a further subjective requirement. ${ }^{38}$ The Commonwealth of Independent States' Terrorism Treaty includes both a "general" special intent directed at terrorizing the population or

${ }^{31}$ Namely the Unlawful Seizure Convention, Civil Aviation Convention, Diplomatic Agents Convention, Hostages Convention, Nuclear Materials Convention, Airport Protocol, Maritime Convention, Fixed Platform Protocol, Terrorist Bombing Convention, Terrorist Financing Convention.

32 OAS Inter-American Convention Against Terrorism, 2002, Art. 1: "For the purposes of this Convention, 'offenses' means the offenses established in the international instruments listed below: [...]."

${ }^{33}$ OAS Convention to Prevent and Punish Acts of Terrorism Taking the Form of Crimes Against Persons and Related Extortion That Are of International Significance, 1971, Art. 2.

${ }^{34}$ OAU Convention on the Prevention and Combating of Terrorism, 1999, Art. I (3) (a)(ii) and (iii): "[...] calculated or intended to: [...] (ii) disrupt any public service, the delivery of any essential service to the public or to create a public emergency; or (iii) create general insurrection in a State."

${ }^{35}$ Ibid., Art. I (3) (a)(i): “[...] calculated or intended to: (i) intimidate, put in fear, force, coerce or induce any government, body, institution, the general public or any segment thereof, to do or abstain from doing any act, or to adopt or abandon a particular standpoint, or to act according to certain principles; or [...]."

${ }^{36}$ Supra note 30 .

${ }^{37}$ Supra note 19.

${ }^{38}$ ASEAN Convention on Counter Terrorism, 2007, Art. 2 (1): "For the purposes of this Convention, "offence" means any of the offences within the scope of and as defined in any of the treaties listed as follows: [...]." 
undermining public safety and a "special" special intent aimed at influencing decision-making by the authorities. ${ }^{39}$

14. The position of the Arab states is contained in three relevant documents. The comprehensive Arab Terrorism Convention abandons the requirement of any additional subjective element explicitly. ${ }^{40}$ The Organisation of the Islamic Conference only requires a "general" special intent directed at terrorizing or harming the people or endangering the environment. ${ }^{41}$ The same applies to the Convention of the Cooperation Council for the Arab States of the Gulf on Combating Terrorism. ${ }^{42}$

\subsection{General Principles ${ }^{43}$}

15. A quick look at some national legislations shows that a "special" special intent is usually required in the alternative to a "general" special intent. Yet, there is a trend in certain countries towards a further "special" special intent requiring a political, religious or ideological purpose.

16. With regard to major Common Law countries there appears to be a tendency towards the additional requirement of a political purpose. In the United Kingdom the Terrorist Act requires that the terrorist offence is committed with the purpose of advancing a political, religious, racial or ideological cause and that the perpetrator had either a "general" special intent directed at causing a state of terror or a "special"

${ }^{39}$ Treaty on Cooperation Among the States Members of the Commonwealth of Independent States in Combating Terrorism, 1999, Art. 1.

40 The Arab Convention on the Suppression of Terrorism, 1998, Art. 1 (2): "Any act or threat of violence, whatever its motives or purposes [...]."

${ }^{41}$ Annex to resolution no: 59/26-P, Convention of the Organisation of the Islamic Conference on Combating International Terrorism, Art. 1 (2): “[...] with the aim of terrorizing people or threatening to harm them or imperiling their lives, honour, freedoms, security or rights or exposing the environment or any facility or public or private property to hazards or occupying or seizing them, or endangering a national resource, or international facilities, or threatening the stability, territorial integrity, political unity or sovereignty of independent States."

42 Convention of the Cooperation Council for the Arab States of the Gulf on Combating Terrorism, Art. 1 (2): “[...] with the aim of terrorizing or harming people or imperiling their lives, freedom or security, or endangering the environment, any facility or any public or private property or occupying or seizing them, or attacking a national resource."

${ }^{43}$ For a comprehensive collection of national legislations see www.unodc.org/ tldb/browse_countries.html. 
special intent aimed at coercing a state to do or abstain from any act. ${ }^{44}$ While the "general" special intent and "special" special intent only need to be fulfilled in the alternative, a political, religious, racial or ideological purpose must always exist ("and"). The terrorism definition of Australia" and New Zealand ${ }^{46}$ list similar requirements. In the Canadian criminal code there is also the requirement of such a purpose but it only needs to exist if the terrorist act is not covered by any of the listed international conventions. ${ }^{47}$ On the other hand, in the USA a political purpose is absent but a "general" and "special" special intent required; yet it is not necessary to prove either of these intents for it is sufficient that the offence "appears" to be intended to intimidate a population or

${ }^{44}$ UK Terrorism Act of 2000, Art. 1 (1): "In this Act 'terrorism' means the use or threat of action where [...] (b) the use or threat is designed to influence the government or an international governmental organisation or to intimidate the public or a section of the public, and (c) the use or threat is made for the purpose of advancing a political, religious, racial or ideological cause." (emphasis added).

${ }^{45}$ Australian Criminal Code, Part 5.3 division 100.1 I terrorist act: “(b) [...] with the intention of advancing a political, religious or ideological cause; and (c) the action is done or the threat is made with the intention of: (i) coercing, or influencing by intimidation, the government of the Commonwealth or a State, Territory or foreign country, or of part of a State, Territory or foreign country; or (ii) intimidating the public or a section of the public."

${ }^{46}$ New Zealand Terrorism Suppression Act, 2002, Art. 5 (2): “[...] for the purpose of advancing an ideological, political, or religious cause, and with the following intention: (a) to induce terror in a civilian population; or (b) to unduly compel or to force a government or an international organisation to do or abstain from doing any act."

${ }^{47}$ Art. 83.01 (1) Canadian Criminal Code: "terrorist activity" means (a) an act or omission that is committed in or outside Canada and that, if committed in Canada, is one of the following offences: [offences of international conventions] (b) an act or omission, in or outside Canada, (i) that is committed (A) in whole or in part for a political, religious or ideological purpose, objective or cause, and (B) in whole or in part with the intention of intimidating the public, or a segment of the public, with regard to its security, including its economic security, or compelling a person, a government or a domestic or an international organization to do or to refrain from doing any act. 
influence a government. ${ }^{48}$ In the Indian terrorist legislation there is the requirement of a "general" special intent directed to intimidate either the government or the people. ${ }^{49}$

17. With regard to major Civil Law countries it can be observed that a "special" special intent is never, if at all, required exclusively as far as the analyzed legislations are concerned. Some legislations do not even provide for a specific terrorist offence. ${ }^{50}$ In France there is only the requirement of a "general" special intent directed at disturbing the public order through intimidation or terror. ${ }^{51}$ In Spain, a "special" special intent is required in the alternative to a "general" special intent. ${ }^{52}$ The German, ${ }^{53}$

\footnotetext{
${ }^{48}$ Section 2331 (1) (b) U.S. Code: "appear to be intended - (i) to intimidate or coerce a civilian population; (ii) to influence the policy of a government by intimidation or coercion; or (iii) to affect the conduct of a government [...]."

49 Terrorist and Disruptive Activities (Prevention) Act, Para. 3: "[...] with intent to overawe the Government as by law established or to strike terror in the people or any section of the people or to alienate any section of the people or to adversely affect the harmony amongst different sections of the people [...]."

${ }^{50}$ This is, for example, the case of Brazil where the Constitution (Art. 4 VIII, 5 XLIII) condemns terrorism and declares any exemption from punishment inadmissible but the criminal law only contains some selective references to the crime without defining it (see for example Art. 20 of the notorious Lei de Segurança Nacional, Lei 7.170 of 14 December 1983).

${ }^{51}$ Articles 421-1 French Code Pénal: "[...] purpose of seriously disturbing the public order through intimidation or terror [...]."

${ }^{52}$ See with regard to the definition of terrorist groups, Art. 571 (3) Spanish Criminal Code: "[...] tengan por finalidad o por objeto subvertir el orden constitucional o alterar gravemente la paz pública [...]"; identically with regard to individuals (Art. 577).

${ }^{53}$ Section 129a German Criminal Code: “[...] intended to seriously intimidate the population, to unlawfully coerce a public authority or an international organisation through the use of force or the threat of the use of force, or to significantly impair or destroy the fundamental political, constitutional, economic or social structures of a state or an international organization." (Transl. by M. Bohlander, The German Criminal Code: a modern English translation, Oxford: Hart, 2008).
} 
Italian, ${ }^{54}$ Austrian, ${ }^{55}$ Dutch $^{56}$ and Danish ${ }^{57}$ terrorism definitions follow basically the EU Framework Decision. ${ }^{58}$ The Finnish Criminal Code is very unspecific as to the subjective requirements of terrorism since it only mentions a "terrorist intent". 59 The Chilean terrorism definition requires a "special" special intent $^{60}$ and alternatively a "general" special intent. ${ }^{61}$ The same applies to the Argentinean ${ }^{62}$ and Mexican ${ }^{63}$ terrorism definitions. Even though the Peruvian Law only requires a general intent, ${ }^{64}$ the jurisdiction has developed the requirement of a "special"

${ }^{54}$ Art. 270 sexies Italian Criminal Code: "[...] e sono compiute allo scopo di intimidire la popolazione o costringere $\mathrm{i}$ poteri pubblici o un organizzazione internazionale a compiere o astenersi dal compiere un qualsiasi atto o destabilizzare o distruggere le strutture politiche fondamentali, costituzionali, economiche e sociali di un Paese o di un?organizzazione internazionale nonché le altre condotte [...]."

${ }^{55}$ Section 278c Austrian Criminal Code: "[...] intended to seriously intimidate the population, to unlawfully coerce a public authority or an international organisation through the use of force or the threat of the use of force, or to significantly impair or destroy the fundamental political, constitutional, economic or social structures of a state or an international organization."

${ }^{56}$ Art. 83, 84 Dutch Criminal Code: „Onder terroristisch oogmerk wordt verstaan het oogmerk om de bevolking of een deel der bevolking van een land ernstige vrees aan te jagen, dan wel een overheid of internationale organisatie wederrechtelijk te dwingen iets te doen, niet te doen of te dulden, dan wel de fundamentele politieke, constitutionele, economische of sociale structuren van een land of een internationale organisatie ernstig te ontwrichten of te vernietigen."

${ }^{57}$ Section 114 Danish Criminal Code: "[...] with the intent to frighten a population to a serious degree or to unlawfully coerce Danish or foreign public authorities or an international organisation to carry out or omit to carry out an act or to destabilize or destroy a country's or an international organisation's fundamental political, constitutional, financial or social structures [...]."

${ }^{58}$ Cf. supra note 30 .

${ }^{59}$ Chap. 34a (1) Finnish Criminal Code: "A person who, with terrorist intent [...]."

${ }^{60}$ Ley 18314 of 16 May 1984, Art. 1 (2a): "Que el delito sea cometido para arrancar resoluciones de la autoridad o imponerle exigencias."

${ }^{61}$ Ibid. Art. 1 (1a): "[...] finalidad de producir en la población o en una parte de ella $[\ldots]$ temor $[\ldots] . "$

${ }^{62}$ Art. 213 ter Argentinean Criminal Code: “[...] asociación ilícita cuyo propósito sea $[\ldots]$ aterrorizar a la población u obligar a un gobierno o a una organización internacional a realizar un acto o abstenerse de hacerlo [...]."

${ }^{63}$ Art. 139 Mexican Criminal Code: “[...] o presionar a la autoridad para. que tome una determinación [...]."

${ }^{64}$ Art. 2 Decreto Ley No. 25475 of 5 Aug. 1992. 
special intent. ${ }^{65}$ In Colombia a "special" special intent is not required as part of the basic offence (tipo básico) but is considered an aggravating circumstance. ${ }^{66}$ In the Chinese criminal code there is no definition of terrorism but only an enumeration of terrorist acts. These offences must generally be committed intentionally but for some offences even negligence is sufficient. ${ }^{67}$ In the Russian criminal code terrorism requires either a "general" special intent directed at frightening the population or a "special" special intent aimed at influencing the government. ${ }^{68}$

\subsection{Further Sources}

18. A further "special" special intent in the form of a political purpose requirement exists also in one UN General Assembly resolution. ${ }^{69}$ Yet, GA Resolutions are not binding (cf. Art. 13 (1) UN-Charter) and create "soft law" at best. ${ }^{70}$

\subsection{Intermediate Conclusion}

19. A "special" special intent is provided for by 2 of the $13 \mathrm{UN}$ Terrorism Conventions. On the regional level, the definition of the EU's Framework Decision, which is binding for all member states of the European Union, ${ }^{71}$ requires two forms of a "special" special intent, but only in the alternative to a "general" special intent. All other regional conventions, if they require a

${ }^{65}$ Cf. for example Polay Campos case, Sala Penal Nacional, Judg. 21 March 2006, p. 130: "El terrorismo tiene como finalidad subvertir el orden constitucional y el orden político en su sentido amplio [...]"; similarly Abimael Guzman case, Sala Penal Nacional, Judg. 13 October 2006, p. 145 ("finalidad política").

${ }^{66}$ Art. 344 no. 3 Colombian Penal Code: "La conducta se ejecute para impedir o alterar el normal desarrollo de certámenes democráticos."

${ }^{67}$ Cf. Art. 114 et seq. Chinese Criminal Code.

${ }^{68}$ Art. 205 Russian Criminal Code: "[...] for the purpose of violating public security, frightening the population, or exerting influence on decision-making by governmental bodies [...]."

${ }^{69}$ UN GA Resolution 49/69, A/RES/49/60, 9 December 1994, Annex I para. 3: "Criminal acts intended or calculated to provoke a state of terror in the general public, a group of persons or particular persons for political purposes [...]."

${ }^{70} \mathrm{Cf}$. Pellet, in A. Zimmermann et al. (eds.), The Statute of the International Court of Justice (Oxford: Oxford University Press, 2006), Art. 38 ICJ Statute, para. 103; A. Cassese, International Law, 2nd ed. (Oxford: Oxford University Press, 2005), p. 335.

${ }^{71}$ Cf. Already supra note 29. 
"special" special intent at all (the OAU convention coming most closely to the EU framework decision), do so in the alternative. In a similar vein, national laws usually require a "special" special intent only in alternative to a "general" special intent. Only some Common Law countries require a further "special" special intent in the form of a political purpose requirement. This requirement is also contained in a UN GA resolution.

\section{DOES INTERNATIONAL LAW PROVIDE FOR A SPECIAL MOTIVE AS AN (ADDITIONAL) ELEMENT OF THE TERRORISM OFFENCE?}

20. Apart from the political purpose requirement which belongs to the intent and was therefore dealt with above, the relevant sources do not provide for subjective elements which explicitly require or imply particular motives. On the contrary, international law quite unequivocally rejects any relevance of motives with regard to the crime of terrorism.

21. None of the 13 international conventions contains any statement about the requirement of a political or ideological motive or motivation. Quite to the contrary, in the Terrorist Bombing, Terrorist Financing and Nuclear Terrorism Conventions it is unequivocally held that, for the purpose of extradition and legal assistance, none of the offences shall be regarded as a political offence. ${ }^{72}$

22. Resolution 1566 of the UN Security Council makes clear that all acts of terrorism are condemned irrespective of their motivation. ${ }^{73}$ In Resolutions 1617, 1735, 1805, 1822 and 1904 the Security Council reaffirmed this notion of terrorism by holding that "any acts of terrorism are criminal and unjustifiable regardless of their motivations". ${ }^{74}$

23. Equally, the specific OAS Terrorism Convention states that "[terrorist acts] shall be considered common crimes of international significance, regardless of motive" ${ }^{75}$ In the Arab Con-

\footnotetext{
${ }^{72}$ Terrorist Financing Convention, Art. 11; Terrorist Financing Convention, Art. 14; Nuclear Terrorism Convention, Art. 15.

${ }^{73}$ UN SC Resolution 1566, S/RES/1566, 8 October 2004, para. 1.

${ }^{74}$ UN SC Resolution 1617, S/RES/1617, 29 July 2005, introductory part para. 2; 1735, S/Res/1735, 22 Dec. 2006, introductory part para. 2; 1805, S/Res/1805, 20 March 2008, introductory part para. 1; 1822, S/Res/1822, 17 June 2008, introductory part para. 2; 1904, S/RES/1904, 17 Dec. 2009, introductory part para. 2 (emphasis added).

${ }^{75}$ OAS Terrorism Convention, supra note 33 (emphasis added).
} 
vention on the Suppression of Terrorism, terrorism is defined as "any act or threat of violence, whatever its motives or purposes" ${ }^{76}$ In the OAU's Terrorism Convention it is even held - in stark contrast to the second qualifier mentioned above (para. 5) - that "Political, philosophical, ideological, racial, ethnic, religious or other motives shall not be a justifiable defence against a terrorist act.",77

24. The same strict position is taken by the GA Resolution $49 / 60$ concerning measures to eliminate international terrorism, where it is expressed that terrorist acts "are in any circumstance unjustifiable, whatever the considerations of a political, philosophical, ideological, racial, ethnic, religious or any other nature that may be invoked to justify them". 78

25. Thus, it is fair to say that the relevant international instruments reject any "politicisation" of the terrorism offence by the inclusion of political, ideological or religious motives or by taking such motives into account in qualifying terrorist conduct.

\section{CONCLUSION}

26. With regard to a "special" special intent requirement the relevant sources of international law reveal the following: While such a requirement is provided for in several (regional) conventions and instruments, it never exists in an exclusive but only in an alternative form to the general special intent requirements. The same applies to those national jurisdictions which require a "special" special intent at all. Thus, while one may consider that the widespread recourse to a "special" special intent element in major national jurisdictions (taking the EU framework decision as the binding position of the $27 \mathrm{EU}$ member states) would make this element a general principle of law within the meaning of Art. 38 (1)(c) ICJ Statute, it would at best allow for the recognition of a "special" special intent as an alternative special intent element.

27. As already made clear at the beginning of this analysis (para. 3), Art. 314 LCC can only be construed in favour of the accused.

\footnotetext{
${ }^{76}$ Arab Terrorism Convention, supra note 40 (emphasis added).

77 OAU Terrorism Convention, supra note 34 (emphasis added).

${ }^{78}$ UN GA Resolution, supra note 69.
} 
While the requirement of an additional "special" special intent would, in principle, restrict the scope of Art. 314 LCC, this is not the case if it were only included, as suggested by international law, in the alternative to the - already existing - "general" special intent. In other words, an alternative special intent requirement, derived from international law, would broaden the scope of Art. 314 LCC since perpetrators with either of the two special intents would qualify as terrorists; only a cumulative inclusion of the two special intents would narrow the scope of Art. 314 LCC.

28. As far as the political purpose requirement - as a kind of further "special" special intent - is concerned, it would certainly restrict the scope of Art. 314 LCC given that it is required cumulatively to a special intent. Yet, the relevant sources indicate that it exists to only such a limited degree that it cannot even be considered a general principle of law.

29. The relevant international law is even clearer with regard to the requirement of a special motive. Such a requirement is not only absent in the relevant sources but it is outrightly rejected by most of them. Apart from that, even if it existed it would not be relevant at the level of the objective elements of the offence (irrelevance thesis, para. 4).

30. It can thus be concluded that there exists no cogent rule in international law which would allow for a bonam partem interpretation or restriction of Art. 314 LCC. On the contrary, the alternative approach taken by international law would entail a broadening of the scope of this provision. To be sure, there are good reasons to argue for a restrictive interpretation of the offence of terrorism, for example by adding a "special" special intent element (in addition to any other subjective element). ${ }^{79}$

\footnotetext{
${ }^{79}$ The scholarly debate has for a long time been critical of the overcriminalization generated by the anti-terrorism legislation and policy, see instead of many Manuel Cancio Meliá, 'Terrorism and Criminal Law: the Dream of Prevention, the Nightmare of the Rule of Law' (2011) 14 New Criminal Law Review, pp. 108-122, at 110: "from my point of view - and this is the common opinion of criminal theorists trained in the civil law tradition - the criminal law's current response to terrorism in the Western world is grossly disproportional to the kind of harm that is threatened by terrorist offenses, even if one takes into account the differences between terrorist crimes and common offenses. Furthermore, I believe that the criminal law's actual response to terrorism is riddled with unconstitutional laws that impose cruel and unusual punishments, unjustifiably criminalize acts that do not clearly inflict cognizable harm, and significantly and inexcusably limit the due process rights of defendants charged with crimes of terrorism."
} 
Yet, again, this approach is not inevitably called for by international law but ultimately the national legislator's decision. 